\title{
How C: N: P stoichiometry in soils and carbon distribution in plants respond to forest age in a Pinus tabuliformis plantation in the mountainous area of eastern Liaoning Province, China
}

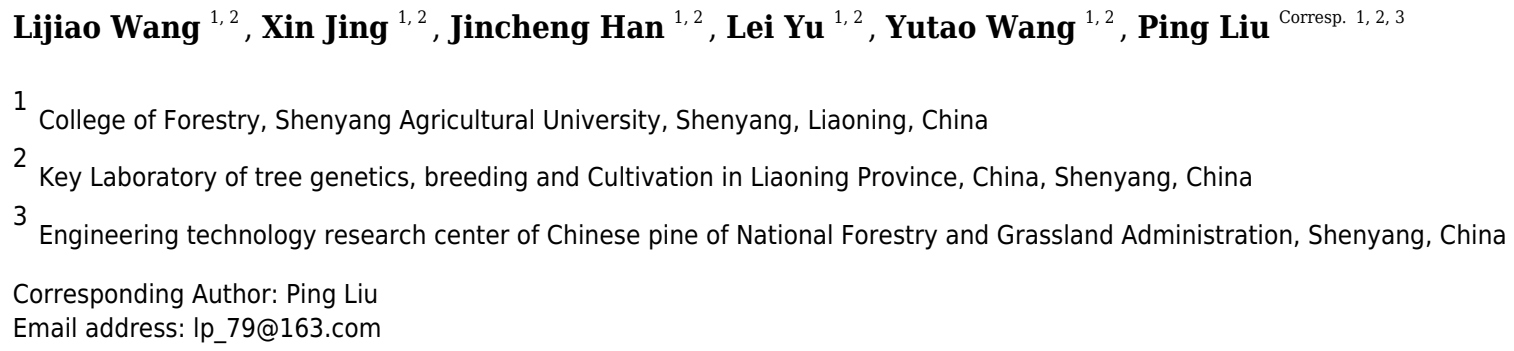

Carbon distribution in plants and ecological stoichiometry in soils are important indicators of element cycling and ecosystem stability. In this study, five forest ages, young forest (YF), middle-aged forest (MAF), near-mature forest (NMF), mature forest (MF), and overmature forest (OMF) in a Pinus tabuliformis plantation were chosen to illustrate interactions among the $\mathrm{C}: \mathrm{N}$ : P stoichiometry in soils and carbon distribution in plants, in the mountainous area of eastern Liaoning, China. Carbon content was highest in the leaves of MAF $\left(505.90 \mathrm{~g} \cdot \mathrm{kg}^{-1}\right)$ and NMF $\left(509.00 \mathrm{~g} \mathrm{~kg}^{-1}\right)$ and the trunks of YF $\left(503.72 \mathrm{~g} \cdot \mathrm{kg}^{-1}\right)$, MF $\left(509.73 \mathrm{~g} \cdot \mathrm{kg}^{-1}\right)$, and OMF $\left(504.90 \mathrm{~g} \cdot \mathrm{kg}^{-1}\right)$, and was lowest in the branches over the entire life cycle of the aboveground components $\left(335.00 \mathrm{~g} \cdot \mathrm{kg}^{-1}\right)$. The carbon content of the fine roots decreased with soil layer depth. In YF, MAF, and NMF, the carbon content of fine roots at $0.5 \mathrm{~m}$ was always higher than that of fine roots at $1 \mathrm{~m}$; however, it was the opposite in MF and OMF. The carbon content of the leaves changed with forest age; however, carbon content of branches, trunks and fine roots did not change significantly. Soil total carbon (TC), total nitrogen (TN), total phosphorus (TP), and available phosphorus (AP) content was highest in the OMF. Soil TC, TN and AP content, and TC: TN, TC: TP and TN: TP ratio decreased with increasing soil depth. Soil TC, TN, and TP content had a significant effect on the carbon content of fine roots $(p<0.05)$. The leaf carbon content and soil element content changed obviously with forest age, and the soil TN, TP and AP increased, which might reduce the carbon content allocation of fine roots. 
2 How C: N: P stoichiometry in soils and carbon

3 distribution in plants respond to forest age in a Pinus

4 tabuliformis plantation in the mountainous area of

5 eastern Liaoning Province, China

6

Lijiao Wang ${ }^{1,2}$, Xin Jing ${ }^{1,2}$, Jincheng Han ${ }^{1,2}$, Lei Yu ${ }^{1,2}$, Yutao Wang ${ }^{1,2}$ and Ping Liu ${ }^{1,2,3}$

$7{ }^{1}$ College of Forestry, Shenyang Agricultural University, Shenyang, China

$8 \quad{ }^{2}$ Key Laboratory of tree genetics, breeding and Cultivation in Liaoning Province, China

$9 \quad{ }^{3}$ Engineering technology research center of Chinese pine of National Forestry and Grassland

10 Administration

11 Corresponding Author:

12 Ping Liu

13120 Dongling Street, Shenyang Agricultural University, 110161, China

14 Email address: 1p_79@163.com

15

16

17

18

19

20

21

22

23

24

25

26

27

28

29

30

31

32

33

34

35

36

37

38

\section{ABSTRACT}

Carbon distribution in plants and ecological stoichiometry in soils are important indicators of element cycling and ecosystem stability. In this study, five forest ages, young forest (YF), middle-aged forest (MAF), near-mature forest (NMF), mature forest (MF), and over-mature forest (OMF) in a Pinus tabuliformis plantation were chosen to illustrate interactions among the $\mathrm{C}$ : N: P stoichiometry in soils and carbon distribution in plants, in the mountainous area of eastern Liaoning, China. Carbon content was highest in the leaves of MAF $\left(505.90 \mathrm{~g} \cdot \mathrm{kg}^{-1}\right)$ and NMF $\left(509.00 \mathrm{~g} \cdot \mathrm{kg}^{-1}\right)$ and the trunks of YF $\left(503.72 \mathrm{~g} \cdot \mathrm{kg}^{-1}\right), \mathrm{MF}\left(509.73 \mathrm{~g} \cdot \mathrm{kg}^{-1}\right)$, and OMF $\left(504.90 \mathrm{~g} \cdot \mathrm{kg}^{-1}\right)$, and was lowest in the branches over the entire life cycle of the aboveground components $\left(335.00 \mathrm{~g} \cdot \mathrm{kg}^{-1}\right)$. The carbon content of the fine roots decreased with soil layer depth. In YF, MAF, and NMF, the carbon content of fine roots at $0.5 \mathrm{~m}$ was always higher than that of fine roots at $1 \mathrm{~m}$; however, it was the opposite in MF and OMF. The carbon content of the leaves changed with forest age; however, carbon content of branches, trunks and fine roots did not change significantly. Soil total carbon (TC), total nitrogen (TN), total phosphorus (TP), and available phosphorus (AP) content was highest in the OMF. Soil TC, TN and AP content, and TC: TN, TC: TP and TN: TP ratio decreased with increasing soil depth. Soil TC, TN, and TP content had a significant effect on the carbon content of fine roots $(p<0.05)$. The leaf carbon content and soil element content changed obviously with forest age, and the soil TN, TP and AP increased, which might reduce the carbon content allocation of fine roots.

\section{INTRODUCTION}

The forest ecosystem is an important part of the terrestrial ecosystem and the Earth's biosphere. Such ecosystems play an important role in regulating and maintaining the Earth's ecosystems (Shao, W., et al., 2017). Forest ecosystems contain plenty of carbon elements, making an important contribution to the global carbon sink (Dixon, R.K., et al., 1994). Forest ecosystem

Peer) reviewing PDF | (2021:02:57804:3:0:NEW 22 Jun 2021) 
39

40

41

42

43

44

45

46

47

48

49

50

51

52

53

54

55

56

57

58

59

60

61

62

63

64

65

66

67

68

69

70

71

72

73

74

75

76

77

78

carbon storage accounts for approximately $56 \%$ of the terrestrial ecosystem carbon storage, of which forest vegetation carbon storage accounts for more than $80 \%$ of the global vegetation carbon storage, and the forest soil carbon pool accounts for more than $40 \%$ of the global soil carbon pool (Brown, S.L., Schroeder, P. \& Kern, J.S., 1999; Houghton, R.A., et al., 2001; Yang, B, et al., 2019). Various human activities, such as burning fossil fuels (Haimson, L. \& Ennis, C, 2004) and deforestation, have led to the continual increase of $\mathrm{CO}_{2}$ gas, forming the greenhouse effect and severely affecting the ecological environment, and by increasing forest carbon storage, greenhouse gas emissions from forests can be avoided, and climate change can be mitigated, thus protecting the ecological environment of the earth ( Liu, W.W., et al., 2015).The forest ecosystem carbon cycle is closely related to the dynamic balance of vegetation and soil carbon storage (Busse, M.D., et al., 2009). Soil is an important factor in terrestrial ecosystems (Gusewell, 2004). As key components of forest ecosystems, trees harbor approximately $42 \%$ carbon in their live biomass (Mcdowell, N. G., et al., 2020; Pan, Y., et al., 2011). Carbon, nitrogen, and phosphorus cycles account for the transfer of nutrients between plants and soil. Carbon is a key building block of structural materials, and nitrogen and phosphorus are major limiting elements in terrestrial natural ecosystems (Zhao, Y.P., 2017).The soil total phosphorus (TP) content is very low (approximately $0.02-2 \%$ ), and China's soil survey estimated that nearly $70 \%$ of its soil is deficient in phosphorus (He, J.L., et al., 2020). The level of soil nutrient content directly affects the growth and development of trees, level of productivity, and ecological function (Wang, Y.S., et al., 2020). The three nutrient elements interact with each other during cycling, and nitrogen and phosphorus affect carbon fixation in soil (Han, W. X., et al., 2005). At present, in relevant local and global studies, the influence of forest age on forest carbon content was found to be particularly important (Wei, H.; Man, X.L., 2019). The results of related studies (Hu, H.Q., et al., 2014; Ming, A.G., et al., 2014; Zhu, J.X., et al., 2017) have shown that within a specific range of forest ages, the carbon storage of vegetation increases with increasing forest age. Mountainous areas in eastern Liaoning Province have a temperate monsoon climate, with dry winter and rainy summer, which are relatively humid and suitable for the growth of Pinus tabuliformis. However, most of the research has been concentrated in the subtropical areas of China, and there are few studies on the eastern area of Liaoning Province. Most scholars have studied the relationships between soil, leaves, and microorganisms, such as Deng Jian et al. (2019). And the relationship between soil and litter in pine forests and compared the soil stoichiometric characteristics among different tree species were studied by scholars (Jiang, P.P., et al., 2016; Wang, Z. and Zheng, F., 2020; Zhang, G.Q., et al., 2018; Qi KB, et al., 2020). There are many studies on carbon content in the leaves of Pinus tabuliformis (Yang, T., 2020; Yan, J.M., 2021; Song, S.M., 2020); however, few studies have been undertaken on studying other organs. There are many studies on ecological stoichiometry characteristics (Wu, X.S., 2020; Liu, G.L., 2020; Jing, L., 2018); however, few analyses have been conducted on the relationship between underground and aboveground areas. Therefore, studying only the carbon content of some organs or studying only the indicators of a period of growth may not reflect the forest carbon sequestration potential and the relationship between plants and the soil in a region.

Peer) reviewing PDF | (2021:02:57804:3:0:NEW 22 Jun 2021) 
79 The local tree species and main pioneer tree for afforestation in Liaoning Province is Pinus

80 tabuliformis, with a total area of approximately $700,000 \mathrm{hm}^{2}$ and a cumulative stock volume of

81 about 36 million $\mathrm{m}^{3}$ (Liu, P. et al., 2019). These species are an important part of the forest re-

82 sources and play very important ecological roles in maintaining the forest ecological balance,

83 saving water resources, and protecting the diversity of wild animals and plants in the eastern

84 mountainous area of Liaoning Province. To implement successful forest management policies, a

85 scientific basis is required (Tewari, V.P., 2016). Therefore, the present study used P. tabuliformis

86 plantation in Fushun County as the research object to determine the content of carbon in different

87 organs (leaves, branches, trunks, and fine roots) and the total carbon (TC), total nitrogen (TN),

88 total phosphorus TP, and available phosphorus (AP) content in the soil over the entire life cycle

89 of a $P$. tabuliformis plantation. The objectives of this study were to test the following three

90 hypotheses: 1) assuming that the carbon distribution of $P$. tabuliformis plantations was age-

91 dependent, the carbon content of the plant organs would change with the different needs of the 92 plants at different growth stages; 2) assuming that the C: N: P stoichiometric characteristics of

93 the soil are highly dependent on stand age and soil depth, the passing of time and change in plant

94 growth requirements would mean that the carbon, nitrogen, and phosphorus elements in all soil

95 layers would change and accumulate to different degrees; and 3) from the growth cycle of YF to

96 OMF, soil C: N: P stoichiometry would significantly affect plant carbon distribution.

\section{MATERIALS \& METHODS}

$98 \quad 2.1$ Study site and experimental design

99 The mountainous area of eastern Liaoning Province, China, belongs to the temperate monsoon

100 climate zone, with a long cold winter and short rainy summer. The average annual precipitation

101 is $700-850 \mathrm{~mm}$, the average annual evaporation is $925-1284 \mathrm{~mm}$, the average annual

102 temperature is $4-1{ }^{\circ} \mathrm{C}$, and the frost-free period is $120-139 \mathrm{~d}$ long. This region belongs to the

103 extension area of the Changbai Mountains, with an altitude of 200-500 m, and a few peaks

104 exceeding $1000 \mathrm{~m}$. The soil is dominated by dark brown loam, generally acidic or neutral loam.

105 In the present study, P. tabuliformis plantation sample plots with similar density and different

106 forest ages were established in the Magu Forest Farm of Fushun County (College of Forestry of

107 Shenyang Agricultural University and Magu Forest Farm, Forestry Department of Fushun

108 Mining Group Co. Ltd approval), Liaoning Province, and included five age classes: young forest

109 (YF), middle-aged forest (MAF), near-mature forest (NMF), mature forest (MF), and over-

110 mature forest (OMF). Each age level had three sample plots, for a total of 15 permanent sample

111 plots. The area of each sample plot was $0.06 \mathrm{hm}^{2}(20 \mathrm{~m} \times 30 \mathrm{~m})$. Two trees representing the

112 average tree height and diameter at breast height $(\mathrm{DBH})$ in each sample plot were selected as

113 standard trees. The DBH, tree height, height under the branch of $P$. tabuliformis, stand density,

114 forest age, and other stand indices were measured using a DBH ruler, tape, and altimeter. The

115 basic data of the samples are shown in Table 1.

1162.2 Aboveground samples

117 The samples were collected in October 2019. Two standard wood plants were selected from each

118 sample plot and a core was drilled through the standard wood from the DBH along a north-south 
119 direction with a growth cone, for a total of 30 cores. The standard wood canopy was divided into 120 three layers: upper, middle, and lower. Two standard branches were selected from each layer, for 121 a total of six standard branches. Each standard branch intercepted one sample branch, and one 122 sample leaf, which were saved in a numbered envelope. A total of 360 samples were collected 123 from 30 standard trees with 180 branch samples and 180 leaf samples. The branch and core

124

125

126

127

128

129

130

131

132

133

134

135

136

137

138

139

140

141

142

143

144

145

146

147

148

149

150

151

152

153

154

155

156

157

158

samples were transported to the laboratory for drying at $80{ }^{\circ} \mathrm{C}$ to a constant weight. The leaves were cured at $105^{\circ} \mathrm{C}$ for $30 \mathrm{~min}$, and then dried to a constant weight at $65^{\circ} \mathrm{C}$. The aboveground part totaled 390 samples.

2.3 Fine roots and soil samples

Soil and fine root samples were collected in October 2019. The underground part of the standard wood was sampled by using the soil drilling method. A cross section of $1 \mathrm{~m} \times 0.5 \mathrm{~m} \times 0.6 \mathrm{~m}$ in length $\times$ width $\times$ depth was dug at the base of each standard wood, and 180 fine roots samples were taken from three soil layers at different depths $(0-20 \mathrm{~cm}, 20-40 \mathrm{~cm}$, and $40-60 \mathrm{~cm}), 0.5 \mathrm{~m}$ and $1 \mathrm{~m}$ from the base of the trunk. And 45 soil samples at three different depths $(0-20 \mathrm{~cm}, 20$ $40 \mathrm{~cm}$, and $40-60 \mathrm{~cm})$ from each plot were collected. All fine roots $(<2 \mathrm{~mm})$ were removed from soil and the soil samples and fine roots that had rocks and debris removed were transported to the laboratory. After the fine roots were washed and air-dried naturally, they were placed in an oven, dehydrated at $105^{\circ} \mathrm{C}$ for $30 \mathrm{~min}$, and dried to a constant weight at $65{ }^{\circ} \mathrm{C}$. Soil samples were naturally air-dried.

2.4 Elements in Pinus tabuliformis and soil samples

Before determining the element content, the samples of leaves, branches, wood cores, fine roots (same distance, same soil layer) from the same sample plot were mixed respectively to form composite samples. The composite samples of wood cores, sample branches, sample leaves, and fine roots were ground and screened with a 60-mesh sieve, whereas the soil composite samples were air-dried and screened with a 100-mesh sieve. All samples were then placed into selfsealing bags, numbered and sealed, and determination.

The TC of plant samples and TC and TN of soil samples were determined using an elemental analyzer (Vario EL III, Elementa Langensel bold, Germany). Soil TP was determined using the $\mathrm{HCLO}_{4}-\mathrm{H}_{2} \mathrm{SO}_{4}$-molybdenum-antimony colorimetric method. The soil AP was determined with the molybdenum-antimony colorimetric method.

2.5 Statistical analysis

Data processing was performed using SPSS 22.0 software (SPSS, Inc., Chicago, IL, USA). The differences in TC content in the different organs and soil TC, TN, TP, AP and its ratio throughout the entire life cycle (from YF to OMF) were examined using single factor variance analysis. Duncan's multiple comparison method was used for significance analysis $(p<0.05)$. Pearson's correlation analysis was used to analyze the correlation between TC, TN, TP, AP and the ratio of the surface soil $(0-20 \mathrm{~cm})$ and the carbon content of different organs over the entire life cycle of the P. tabuliformis plantation.

\section{RESULTS}

3.1 Carbon distribution of Pinus tabuliformis plantation

Peer] reviewing PDF | (2021:02:57804:3:0:NEW 22 Jun 2021) 
159

160

161

162

163

164

165

166

167

168

169

170

171

172

173

174

175

176

177

178

179

180

181

182

183

184

185

186

187

188

189

190

191

192

193

194

195

196

197

198

\subsubsection{Aboveground carbon distribution}

The carbon content over the entire life cycle of the $P$. tabuliformis plantation was 489.83-509.00 $\mathrm{g} \cdot \mathrm{kg}^{-1}$ in the leaves (Fig.1A), 335.00-471.43 $\mathrm{g} \cdot \mathrm{kg}^{-1}$ in the branches (Fig.1B), and 489.87-509.73 $\mathrm{g} \cdot \mathrm{kg}^{-1}$ in the trunks (Fig.1C). With a change in forest age, the carbon content of the leaves gradually increased and then decreased, reaching a maximum in NMF. There were significant differences between the carbon content in forest ages $(p<0.05)$, except in MAF and NMF, and MF and OMF (Fig.1A). The carbon content of the branches decreased from YF to MAF, and decreased after a slight increase in MF. There were significant differences between the carbon content in forest ages $(p<0.05)$, except in MAF, NMF, and OMF (Fig.1B). The carbon content of the trunks only in the NMF showed significant differences between MF and OMF $(p<0.05)$ (Fig.1C).

\subsubsection{Underground carbon distribution}

The carbon content of fine roots ranged from 415.20 to $480.37 \mathrm{~g} \cdot \mathrm{kg}^{-1}$ over the entire life cycle of the $P$. tabuliformis plantation. There were no significant differences among the carbon content of fine roots $(0.5 \mathrm{~m})$ in the soil layers of YF, NMF, and MF. There were significant differences between the $0-20 \mathrm{~cm}$ soil layer $(p<0.05)$ and other soil layers in the MAF and OMF age groups $(p<0.05)$ (Fig.2A). In the $0-20 \mathrm{~cm}$ soil layer, the carbon content of fine roots $(0.5 \mathrm{~m})$ in MAF and YF, NMF and OMF were significantly different $(p<0.05)$. In the $20-40 \mathrm{~cm}$ soil layer, there was significant difference among MF and OMF $(p<0.05)$. In the 40-60 cm soil layer, YF, MF, and OMF showed significant differences $(p<0.05)$. However, for the carbon content of fine roots $(1 \mathrm{~m})$ in all soil layers of different forest ages, only the $40-60 \mathrm{~cm}$ and $0-20 \mathrm{~cm}$ layers in NMF showed significant differences $(p<0.05)$ (Fig.2B). In the $0-20 \mathrm{~cm}$ soil layer, there were significant differences between NMF, YF, and OMF $(p<0.05)$. In the $20-40 \mathrm{~cm}$ soil layer, there was no significant difference among the different forest ages. In the $40-60 \mathrm{~cm}$ soil layer, the carbon content of fine roots $(1 \mathrm{~m})$ in the YF was significantly different from that in MAF, MF, and OMF $(p<0.05)$, and between NMF and MF $(p<0.05)$. The results showed that the carbon content of fine roots decreased with soil layer depth, and there was a trend of first increasing and then decreasing with an increase in forest age.

\subsubsection{TC distribution}

In the YF, the order of carbon content of the different organs was trunks $>$ leaves $>$ branches $>$ fine roots; in MAF and NMF the order was leaves $>$ trunks $>$ fine roots $>$ branches, and in MF and OMF the order was trunks $>$ leaves $>$ fine roots $>$ branches (Table 2). The carbon content of the aboveground parts was significantly different from that of fine roots over the entire life cycle of the $P$. tabuliformis plantation. The carbon content of the leaves and trunks was significantly different from that of the branches, except in the YF. However, there was no significant difference between the carbon content of fine roots in the same forest age. The carbon content of the branches was the lowest of the aboveground components, and the carbon content of the fine roots decreased with the soil layer depth. In YF, MAF, and NMF, the carbon content of fine roots at $0.5 \mathrm{~m}$ was consistently higher than that of fine roots at $1 \mathrm{~m}$ in the same soil layer; meanwhile, the opposite results were found in MF and OMF.

Peer) reviewing PDF | (2021:02:57804:3:0:NEW 22 Jun 2021) 
199

200

201

202

203

204

205

206

207

208

209

210

211

212

213

214

215

216

217

218

219

220

221

222

223

224

225

226

227

228

229

230

231

232

233

234

235

236

237

238

3.2 Soil ecological stoichiometric characteristics

\subsubsection{Soil TC, TN, TP, and AP content}

In the surface soil $(0-20 \mathrm{~cm})$, the value of soil TC content was varied between $11.25-37.82 \mathrm{~g} \cdot \mathrm{kg}^{-}$

1 , the value of soil TN content was varied between $0.69-2.95 \mathrm{~g} \cdot \mathrm{kg}^{-1}$, the value of soil TP content was varied between $0.28-1.32 \mathrm{~g} \cdot \mathrm{kg}^{-1}$, and the value of soil AP content was varied between 13.57-18.57 $\mathrm{mg} \cdot \mathrm{kg}^{-1}$. And in all soil layers, over the entire life cycle of the $P$. tabuliformis

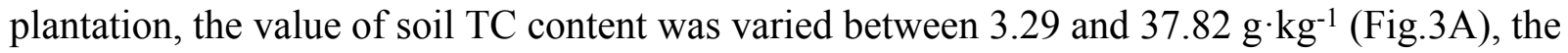
value of soil TN content was varied between 0.22 and $2.95 \mathrm{~g}^{\circ} \mathrm{kg}^{-1}$ (Fig.3B), the value of soil TP content was varied between 0.23 to $1.61 \mathrm{~g} \cdot \mathrm{kg}^{-1}$ (Fig.3C), and the value of soil AP content was varied between $13.52-20.99 \mathrm{mg} \cdot \mathrm{kg}^{-1}$ (Fig.3D). In some forest ages, the TC and TN content in the 0-20 cm soil layer was significantly different from those in the other soil layers; however, the TC and TN content in the $20-40 \mathrm{~cm}$ and $40-60 \mathrm{~cm}$ soil layers were not significantly different over the entire life cycle. The TP and AP content in the soil did not change significantly with soil layer and forest age, except for the AP content in NMF. Therefore, the TC and TN content in the soil decreased with soil layer depth, and that of TC, TN, TP, and AP was the highest in the OMF in each soil layer, except for AP in the $20-40 \mathrm{~cm}$ soil layer.

3.2.2 Stoichiometric ratio of soil $\mathrm{TC}, \mathrm{TN}$, and $\mathrm{TP}$

In the surface soil $(0-20 \mathrm{~cm})$, soil TC: TN ratio ranged from 12.82 to 18.00 , soil TC: TP ratio ranged from 11.01 to 67.84 , and soil TN: TP ratio ranged from 0.73 to 3.97 . And in all soil layers, over the entire life cycle of the P. tabuliformis plantation, soil TC: TN ratio ranged from 10.64 to 18.00 (Fig.4A), soil TC: TP ratio ranged from 4.01 to 67.84 (Fig.4B), and soil TN: TP ratio ranged from 0.29 to 3.97 (Fig.4C). There was no significant difference in soil TC: TN ratio among the different soil layers in the same forest age. In YF, MAF, and NMF, soil TC: TP and soil TN: TP ratio showed significant differences among the soil layers. The soil TC: TN, TC: TP and TN: TP ratio varied with the content of soil TC, TN and TP. So they show different significant differences at different ages. In the same forest age, soil TC: TN, soil TC: TP, and soil TN: TP ratio showed a downward trend with soil layer depth, and soil TC: TP and soil TN: TP ratio first increased and then decreased with an increase in forest age.

3.3 Correlation of soil ecological stoichiometry and its ratio with the carbon content in different organs

There was a significant positive correlation between the carbon content of leaves and soil TN: TP ratio in the YF (Fig.5A). The carbon content of leaves had a significant positive correlation with soil AP content (Fig.5B), and the carbon content of trunks had a significant positive correlation with soil TN: TP ratio in MF (Fig.5C). The results showed that soil stoichiometry and its ratio had a weak correlation with the aboveground carbon content.

Soil TC: TN ratio was significantly positively correlated with the fine roots $(0.5 \mathrm{~m})$ in the $20-40$ $\mathrm{cm}$ soil layer. Soil TN and TP content was significantly negatively correlated with the fine roots $(1 \mathrm{~m})$ in the $0-20 \mathrm{~cm}$ soil layer, and TC: TP ratio was significantly positively correlated with the fine roots in the YF (Fig.6A, B, C, and D). The soil AP content was significantly negatively correlated with the fine roots $(0.5 \mathrm{~m})$ in the $20-40 \mathrm{~cm}$ soil layer in the MAF (Fig.6E). Soil TC 
239 content was significantly negatively correlated with the fine roots $(0.5 \mathrm{~m})$ in the $40-60 \mathrm{~cm}$ soil 240 layer (Fig.6F). And the soil TN content soil was significantly negatively correlated with the fine 241 roots $(0.5 \mathrm{~m})$ in the $20-40 \mathrm{~cm}$ soil layer in the NMF (Fig.6G). Soil TC: TP ratio was significantly 242 positively correlated with the fine roots $(0.5 \mathrm{~m})$ in the $40-60 \mathrm{~cm}$ soil layer in the MF (Fig. $6 \mathrm{H}$ ), 243 and the soil TN content was significantly negatively correlated with fine roots $(1 \mathrm{~m})$ in the 20-40 $244 \mathrm{~cm}$ soil layer in the OMF (Fig.6I). Therefore, the soil stoichiometry and its ratio strongly 245 correlated with the carbon content of fine roots.

\section{DISCUSSION}

247 4.1 Carbon distributions over the life cycle of Pinus tabuliformis plantation

248 The result of this part of the study is consistent with our first hypothesis. The carbon content in 249 the leaves of $P$. tabuliformis was obviously higher than that $\left(464 \mathrm{~g} \cdot \mathrm{kg}^{-1}\right)$ of the 492 terrestrial 250 plants worldwide studied by Elser et al. (2000), indicating a high content of organic compounds 251 in P. tabuliformis leaves (Wang, Z.F. \& Zheng, F.L., 2018). The carbon content of leaves,

252

253

254

255

256

257

258

259

260

261

262

263

264

265

266

267

268

269

270

271

272

273

274

275

276

277

278

branches, and trunks was obviously different from that reported by Liu et al. (2015) and which may be due to the comprehensive influence of different factors, including sampling time, forest age, site conditions, climate, and environment of the sampling site (Wang, Z.F.\& Zheng, F.L., 2018). The carbon content of the branches decreased with an increase in forest age, whereas the carbon content of the trunks did not change significantly with an increase in forest age, which was consistent with that reported by Zhang et al. (Zhang, G.Q., et al., 2018). This may be due to the difference in the carbon synthesis rate and distribution strategy in the leaves and branches at different ages (Lei, H., 2019). The carbon content in the leaves and branches of P. tabuliformis with an increase in forest age, indicating that the fixed carbon content decreased with the growth of plant organs, and the change in content was easily affected by a variety of factors, including sampling time, forest age, and soil physical and chemical properties (Zhang, H.Y., et al., 2013). During the early growth stage of trees, with an increase in growth rate, the carbon distribution of fine roots closer to the trunk of $P$. tabuliformis increased, and to meet the needs of tree growth, the fine roots absorbed water and nutrients continuously. However, during the later growth stage of trees, when the growth rate reached the maximum, the growth rate slowed down or stopped, and the roots mainly grew and spread around to expand the absorption area of nutrients.

Therefore, during the later growth stage of trees, the fine roots farther away from the trunk had higher carbon content.

4.2 Soil ecological stoichiometry characteristics over the life cycle of Pinus tabuliformis plantation

The accumulations of soil TC, TN, and AP are long-term process, and the soil TP content had the most obvious accumulation trend with an increase in forest age. This is consistent with our second hypothesis. The present study was consistent with the previous research have also found that the TC, TN, and TP content of soil in OMF was the highest (Zhao, F.Z., et al., 2012). The results of the present study also showed that the surface layer $(0-20 \mathrm{~cm})$ had the highest TC and TN content, showing the phenomenon of "surface accumulation," which is consistent with the results of previous studies and might be related to the high activity of soil surface soil

Peer) reviewing PDF | (2021:02:57804:3:0:NEW 22 Jun 2021) 
279 microorganisms (Wang, Z.F.\& Zheng, F.L., 2018). The surface soil TN content $\left(2.95 \mathrm{~g} \cdot \mathrm{kg}^{-1}\right)$ was 280 higher than the national average total nitrogen content $\left(1.88 \mathrm{~g} \cdot \mathrm{kg}^{-1}\right)$, indicating that the $P$. 281 tabuliformis plantation in this area had a certain effect on increasing the soil nitrogen content. 282 In the present study, the soil TP content $\left(1.61 \mathrm{~g} \cdot \mathrm{kg}^{-1}\right)$ was lower than the global average $(2.8$ $\left.283 \mathrm{~g} \cdot \mathrm{kg}^{-1}\right)$ (Ren, S.J., et.al, 2007), which is consistent with the fact that the soil TP content in China 284 is generally lower than the global level (Yang, J.J., et.al, 2014). It may be related to 285 environmental conditions, weathering, and soil erosion in the mountainous areas of eastern 286 Liaoning Province. The results was consistent with the previous research have also found that 287 there was no significant difference in the TP content among all soil layers (Wei, X.; Shao, M., 288 2007). This was mainly due to the different carbon, nitrogen, and phosphorus sources (Wang, S.; 289 290 $Y u, G ., 2008)$. Carbon and nitrogen elements accumulate on the soil surface, migrate downward by leaching, and are affected by plant absorption and utilization. Phosphorus is mainly affected by the weathering of the soil parent material. Moreover, phosphorus is a sedimentary mineral that migrates relatively little in the soil, and is evenly distributed throughout the entire soil layer (Cui, G.Y.; Cao, Y. \& Chen, Y.M., 2015). The weathering of rocks and minerals is a stable and lengthy process, which is a major source of soil AP. Therefore, their spatial variability in the soil

295

296

297

298

299

300

301

302

303

304

305

306

307

308

309

310

311

312

313

314

315

316

317

318 is small and changes in the soil layer depths are not significant (Liu, X.Z. et al., 2010). In general, the soil TC: TN ratio is inversely proportional to the decomposition rate of soil organic matter (Majdi, H., et al., 2004). The soil TC: TN ratio (18.00) in the present study area was higher than the Chinese soil TC: TN ratio (10.1-12.1) and the global average (13.33). Therefore, the decomposition rate of organic matter and mineralization in the study area were relatively slow. However, except for NMF in this study, soil TC: TN ratio in other aged $P$. tabuliformis plantations decreased with forest age, indicating that with the increase of forest age, the mineralization rate of organic matter increased, and the demand for soil nutrients gradually increased. If the soil TC: TP ratio is relatively low, it is conducive to the release of nutrients from microorganisms in the process of organic matter decomposition and to promote the increase of available phosphorus in the soil. On the contrary, when soil TC: TP ratio is relatively high, there will be limited phosphorus in the process of decomposition of organic matter by microorganisms. Therefore, there will be competition with plants for soil inorganic phosphorus, which is not conducive to the growth of plants and the increase of NPP (Wang, J.L., et al., 2014). In the present study, soil TC: TP ratio (67.84) was higher than the average value of 61 in China, indicating that microorganisms and plants in the surface soil layer of the study area compete for phosphorus, which is not conducive to growth (Ning, Y., 2020). In the present study, soil TN: TP ratio (3.97) was lower than the mean value of soil TN: TP ratio in China (5.2), and the mean value increasing at the beginning and then decreasing with the change in forest age, but the difference was not statistically significant. The reason may be that with the growth of $P$. tabuliformis, the contents of nutrient elements in soil decreased to different degrees, and the demand for phosphorus was stronger than that for carbon and nitrogen. With the increase in forest age, the uptake of nutrients slows down, and the return of nutrients from the litter supplements the soil. In the present study, soil TN content, TC: TN and TC: TP ratios were

Peer] reviewing PDF | (2021:02:57804:3:0:NEW 22 Jun 2021) 
319 higher than the national average, whereas TN: TP ratio was lower, indicating that carbon, 320 nitrogen, and phosphorus content in the soil was adequate.

3214.3 Correlation among components over the life cycle of Pinus tabuliformis plantation

322 According to Garnier (1998) theory, there is a positive correlation between the content of an

323 element in the soil and the content of an organ in the plant, and this element is the limiting

324 nutrient. In the present study, the results showed that the carbon content of MF leaves was

325 significantly positively correlated with the soil AP content, whereas the soil TN, TP, and AP

326 content were significantly negatively correlated with the fine roots carbon content. Therefore, the

327 soil AP content in MF was the limiting nutrient for the leaves, and soil TN, TP, and AP were the

328 limiting nutrients for fine roots. Given that soil nutrients have significant effects on fine root

329 biomass and nutrients (Chen, L, et al., 2016), it is not surprising that the fine root carbon and

330 nitrogen contents were correlated with the soil carbon and nitrogen contents. There were similar

331 findings, which was consistent with our third hypothesis (Chen, L.L. et al., 2018; Yuan, Z.Y., et

332 al., 2011). According to the third hypothesis proposed by Nadelhoffer (Nadelhoffer, K.J. ,

333 2000)(which is the most well-supported hypothesis), with the improvement of soil nutrient

334 availability, the fine root productivity of trees increases, the life span is shortened, turnover is

335 accelerated, and the fine root biomass decreases. The reduction in the biomass of fine roots of

336 trees can be explained by the optimal allocation and cost-effectiveness theory, that is, the

337 improvement of nutrient availability might reduce the carbon allocation of fine roots. In the $P$.

338 tabuliformis plantation soil in this area, the TN, TP, and AP content in the soil was assumed to

339 be too high, which might reduce the carbon distribution of the fine roots. Among the different

340 organs of P. tabuliformis in this study area, only the leaves were significantly correlated with the

341 soil AP content. There was no correlation between branches, trunks, and soil nutrients. These

342 results were consistent with those of Jiang et al. (Jiang, P.P. et al., 2016).

\section{CONCLUSIONS}

344 The influence of $P$. tabuliformis plantation age on the underground element content was greater

345

346

347

348

349

350

351

352

353

354

355

356

357 than that on the carbon content in the aboveground components. The carbon content of the leaves and fine roots, and the TC, TN, and TP content of the soil changed with forest age, whereas the carbon content of the branches and trunks and soil AP did not change significantly with forest age. At the start of the growth, fine roots closer to the trunk had higher carbon content; however, the reverse was true during the later growth stage. Except for soil TP and AP content, the carbon content of fine roots and soil stoichiometry and their ratios decreased with increasing soil depth. The accumulations of soil TC, TN, and AP are long-term process, and TP content has the most evident accumulation trend with an increase in forest age. The analysis showed that the $P$. tabuliformis plantation had a certain effect on increasing the soil nitrogen content, and the carbon, nitrogen, and phosphorus content in the soil was adequate. Soil nitrogen and phosphorus content had a significant effect on the fine roots. In forest management, the soil of $P$. tabuliformis plantation in the eastern mountainous area of Liaoning Province is abundant in nitrogen and phosphorus, so it is unnecessary to apply additional nitrogen and phosphorus 
358

359

360

361

362

363

364

365

366

367

368

369

370

371

372

373

374

375

376

377

378

379

380

381

382

383

384

385

386

387

388

389

390

391

392

393

394

395

396

397

398

399

400

401

402

403

404

fertilizer. These results could provide a useful reference for the management of $P$. tabuliformis plantations and the study of carbon sinks in the mountainous area of eastern Liaoning Province.

\section{ACKNOWLEDGEMENTS}

We are particularly grateful to the following lab members for their help: Z.J., B.Q., and M.L.

\section{REFERENCES}

Brown SL, Schroeder P, Kern JS. 1999. Spatial distribution of biomass in forests of the eastern USA. Forest Ecol. Manag 123:81-90.

Busse MD, Sanchez FG, Ratcliff AW, Butnor JR, Carter EA, Powers RF. 2009. Soil carbon sequestration and changes in fungal and bacterial biomass following incorporation of forest residues. Soil Biol. Biochem 41:220-227.

Chen LL, Deng Q, Yuan ZY, Mu XM, Kallenbach RL. 2018. Age-related C: N: P stoichiometry in two plantation forests in the Loess Plateau of China. Ecol. Eng 120:14-22.

Chen LL, Mu XM, Yuan ZY, Deng Q, Chen YL, Yuan LY, Ryan LT, Kallenbach RL. 2016. Soil nutrients and water affect the age-related fine root biomass but not production in two plantation forests on the Loess Plateau, China. J. Arid Environ 135:173-180.

Cui GY, Cao Y, Chen YM. 2015. Nitrogen and phosphorus stoichiometric characteristics of forest ecosystem components in Shaanxi Province. J. Plant Ecol 39:1146-1155.

Deng J, Zhang D, Zhang W, Ren CJ, Hao WH, Liu C, Han XH, Yang GH. 2019. Carbon, nitrogen, and phosphorus stoichiometry and homeostasis characteristics of leaves, soil, and microbial biomass of Robinia pseudoacacia forests in the loess hilly region of China. Acta Ecologica Sinica 39:5527-5535.

Dixon RK, Brown S, Houghton RA, Solomon AM, Trexler MC, Wisniewski J. 1994. Carbon pools and flux of global forest ecosystems. Science 263:185-190.

Elser JJ, Fagan WF, Denno RF, Dobberfuhl DR, Folarin A, Huberty A, Interlandi S, Kilham SS, McCauley E, Schulz KL, Siemann EH, Sterner RW. 2000. Nutritional constraints in terrestrial and freshwater food webs. Nature 408:578-580.

Garnier E. 1998. Interspecific variation in plasticity of grasses in response to nitrogen supply. Population biology of grasses 155-181.

Gusewell, S. 2004. N: P ratios in terrestrial plants: variation and functional significance. New Phytologist 164:243-266.

Haimson L, Ennis C. 2004. Common questions about climate change. Sponsored by $U N E P / W H O 25$.

Han WX, Fang JY, Guo DL, Zhang Y. 2005. Leaf nitrogen and phosphorus stoichiometry across 753 terrestrial plant species in China. New Phytologist 168:377-385.

He JL, Song YK, Wang JN, Zhou J, Wang CY, Cha L, Shi N, Wu Y, Bai JW. 2020. The spatial and temporal variations of soil C, N, P ecological stoichiometry across the alpine forests and grassland ecotone at Minjiang Headwaters. Chin J. Appl Environ Biol. https://doi.org/10.19675/j.cnki.1006-687x.2020.04055.

Houghton RA, Lawrence KT, Hackler JL, Sandra Brown. 2001. The spatial distribution of forest biomass in the Brazilian Amazon: A comparison of estimates. Glob. Chang. Biol 7:731746.

Hu HQ, Luo BZ, Wei SJ, Wei SW, Wen ZM, Sun L, Luo S, Wang LM, Ma HB. 2014. Estimating biological carbon storage of five typical forest types in the Daxing'an Ling Mountains, Heilongjiang, China. Acta Ecologica Sinica 35:5745-5760.

Jiang PP, Cao Y, Chen YM, Wang F. 2016. Variation of C, N, and P stoichiometry in plant tissue, litter, and soil during stand development in Pinus tabuliformis plantation. Acta Ecologica Sinica 36:6188-6197. 
405 Jing L, Zhou Y, Lu C, Zhao JR, Lei GC. 2018. Ecological stoichiometry characteristics of leaf 406 and soil carbon, nitrogen, and phosphorus of three-age poplar plantations in Dongting Lake 407 Wetland. Acta Ecologica Sinica 38(18):6530-6538.

408 Lei H. 2019. The stoichiometric characteristics of carbon, nitrogen and phosphorus of main 409 shelter forests in Horqin Sandy Land. Liaoning Technical University, MA thesis.

410 Liu BY, Chen YM, Cao Y, Wu X. 2015. Storage and allocation of carbon and nitrogen in Pinus 411 tabuliformis plantations on the south slope of the East Qinling Mountains, China. Chinese J. 412 Appl. Ecol. Mar 26:643-652.

413 Liu GB, Liu S, Cui YS, Wang ZL, Tian JX, Wang WR, Zhao SB. 2020. The stoichiometric 414 characteristics of soil carbon, nitrogen and phosphorus in Larix olgensis plantations of different 415 ages. Journal of Beihua University (Natural Science Edition) 21(03):306-310.

416 Liu P, Han JC, Yu L, Jing X, Wang YT. 2019. Study on biomass of Pinus tabuliformis 417 plantation in the mountainous area of eastern Liaoning Province. J. Agr. Uni 50:740-746.

418 Liu WW, Wang XK, Lu F, Ou Yang ZY. 2015. Global forest ecosystem carbon storage,

419 carbon sequestration capacity estimation and its regional characteristics. Journal of Applied 420 Ecology 26(09):2881-2890.

421 Liu XZ, Zhou GY, Zhang DQ, Liu SZ, Chu GW, Yan JH. 2010. Stoichiometric

422 characteristics of $\mathrm{N}$ and $\mathrm{P}$ in plants and soils at different stages of succession in tropical forests 423 of South Asia. J. Plant Ecol 34: 64-71.

424 Majdi H, Ohrvik J. 2004. Interactive effects of soil warming and fertilization on root

425

426 production, mortality, and longevity in a Norway spruce stand in Northern Sweden. Global

427

428

429

430

431

432

433

434

435

436

437

438

439

440

441

442

443

444

445

446

447

McDowell NG; Allen CD; Anderson-Teixeira K ; Aukema BH; Bond-Lamberty B; Chini L; Clark JS, Dietze M, Grossiord C, Hanbury-Brown A, Hurtt GC, Jackson RB, Johnson DJ, Kueppers L, Lichstein JW, Ogle K, Poulter B, Pugh TAM, Seidl R, Turner MG, Uriarte M, Walker AP, Xu CG. 2020. Pervasive shifts in forest dynamics in a changing world. Science (New York, N.Y.) 368.

Ming AG, Jia HY, Tian ZW, Tao Y, Lu LH, Cai DX, Shi ZM, Wang WX. 2014.

Characteristics of carbon storage and its allocation in Erythrophleum fordii plantations with different ages. Chinese J. Appl. Ecol 25:940-946.

Nadelhoffer KJ. 2000. The potential effects of nitrogen deposition on fine root production in forest ecosystems. New Phytologist 147: 131-139.

Ning Y. 2020. Study on soil-plant ecological stoichiometric characteristics of Pinus tabularis forest ecosystem. MA thesis, Beijing Forestry University.

Pan YD, Birdsey RA, Fang JY, Houghton R, Kauppi PE, Kurz WA, Phillips OL, Shvidenko A, Lewis SL, Canadell JG, Ciais P, Jackson RB, Pacala SW, McGuire AD, Piao SL, Rautiainen A, Sitch S, Hayes D. 2011. A large and persistent carbon sink in the world's forests. Science 333:988-993.

Qi KB, Pang XY,Yang B,Bao WK. 2020. Soil carbon, nitrogen and phosphorus ecological stoichiometry shifts with tree species in subalpine plantations. Peer $J \mathbf{8}$.

Ren SJ, Yu GR, Tao B, Wang SQ. 2007. Study on the stoichiometric characteristics of leaf nitrogen and phosphorus of 654 plant species in the north-south transect in eastern China.

448 Environmental science 28 (12):2665-2673.

449

Shao WW, Cai JY, Wu HB, Liu JH, Zhang HX, Huang H. 2017. An assessment of carbon storage in China's arboreal forests. Forests 8:110. 
450 Song SM, Zhou Y, Zhang J. 2021. Ecological stoichiometric characteristics of carbon, nitrogen 451 and phosphorus in leaves of Chinese fir plantations in different site types. Journal of Northwest 452 Sci-Tech University of Agriculture and Forestry (Natural Science Edition) 06:2-17.

453 Tewari VP. 2016. Forest inventory, assessment, and monitoring, and long-term forest 454 observational studies, with special reference to India. Forest Sci. Tech 24-32.

455 Wang JL, Zhong ZM, Wang ZH, Yu Q, Shen ZX, Zhang XZ, Hu XX, Da CZG. 2014. 456 Distribution characteristics of soil carbon to phosphorus ratio in the alpine grassland ecosystem 457 on the Qinghai-Tibet Plateau. Acta Prataculturae 23(02):9-19.

458 Wang S, Yu G. 2008. Ecological chemometrics characteristics of carbon, nitrogen and 459 phosphorus elements in ecosystems. J. Ecol 28:3937-3947.

460 Wang YS, Ma BM, Gao HP, Wang BT, Li S, Dong XQ. 2020. Response of soil nutrients and 461 their stoichiometric ratios to stand density in Pinus tabuliformis and Robinia pseudoacacia 462 plantations in the loess region of western Shanxi Province, northern China. J. Beijing Forestry 463 University 42:81-93.

464 Wang Z, Zheng F. 2020. Ecological stoichiometry of plant leaves, litter and soils in a secondary 465 forest on China's loess plateau. Peer J 8(1):e10084.

466 Wang ZF, Zheng FL. 2018. C, N, and P stoichiometric characteristics of Pinus tabuliformis 467 plantation in the Ziwuling region of the Loess Plateau. Acta Ecologica Sinica 38:6870-6880.

468 Wei H, Man XL. 2019. Carbon storage and its allocation in Betula platyphylla forests of 469 different ages in cold temperate zone of China. Chinese J. Plant Ecol 43: 843-852.

470 Wei X, Shao M. 2007. Characteristics of soil nutrient distribution in small watershed in gully 471 region on loess plateau. J. Ecol 27:603-612.

472 Wu XS. 2020. Stoichiometric characteristics of carbon, nitrogen and phosphorus in rhizosphere

473

474

475

476

477

478

479

480

481

482

483

484

485

486

487

488

489

490

491

492 and non-rhizosphere soils of Chinese fir at different ages. Forestry survey and design 40:8-12. Yan JM, Zhang SH, Wang M, Hang W, Qian S, Qiu D, Tao Y. 2021. Seasonal dynamics of the NPK stoichiometric characteristics of the branches and leaves of the endangered five-needle pine in Dabie Mountains. Plant research 41 (03):395-407.

Yang B, Zhang WH, Lu YL, Zhang WW, Wang YA. 2019. Carbon storage dynamics of secondary forest succession in the central loess plateau of China. Forests 10(4):342.

Yang JJ, Zhang XR, Ma LS, Chen YA, Dang TH, An SS. 2014. Study on the ecological stoichiometric relationship of different components of Robinia pseudoacacia forest on the Loess Plateau. Acta Pedologica Sinica 51(1):133-142.

Yang T, Zhong QL, Li BY, Cheng DL, Xu CB, Yu H, Zou YX. 2020. Stoichiometric characteristics of carbon, nitrogen and phosphorus in leaves and fine roots of three functional tree seedlings and their allometric relationships. Journal of Applied Ecology 31(12):4051-4057. Yuan ZY, Chen HYH, Reich PB. 2011. Global-scale latitudinal patterns of plant fine-root nitrogen and phosphorus. Nature Commun 2: 55-73.

Zhang GQ, Zhang P, Chen YM, Peng SZ, Cao Y. 2018. Stoichiometric characteristics of Robinia pseudoacacia and Pinus tabuliformis plantation ecosystems in the loess hilly-gully region, China. Acta Ecologica Sinica 38:1328-1336.

Zhang HY, Wu HH, Yu Q, Wang ZW, Wei CZ, Long M, Kattge J, Smith M, Han XG. 2013. Sampling date, leaf age and root size: Implications for the study of plant $\mathrm{C}: \mathrm{N}$ : $\mathrm{P}$ stoichiometry. Plos One 8(4): e60360. 
493 Zhao FZ, Han XH, Yang GH, Tong XG, Kang K, Du JH. 2012. The variation characteristics 494 of soil organic carbon and nitrogen density in different returning farmland to forestland in loess 495 hilly region. Soil Water Cons. Res 19:43-52.

496 Zhao YP, Cao Y, Chen YM, Peng SZ. 2017. Ecological Stoichiometric Characteristics of

497 Forest Ecosystem in Loess Hilly and Gully Region. Acta Ecologica Sinica 16(37):5451-5460.

498 Zhu JX, Zhou XL, Fang WJ, Xiong XY, Zhu B, Ji CJ, Fang JY. 2017. Plant debris and its 499 contribution to ecosystem carbon storage in successional Larix gmelinii forests in northeastern 500 China. Forests 8, 191-200.

501 


\section{Table $\mathbf{1}$ (on next page)}

Basic information of sample trees 
1 Table 1.Basic information of sample trees

\begin{tabular}{ccccc} 
Age class & $\begin{array}{c}\text { Mean } \\
\text { Age (a) }\end{array}$ & $\begin{array}{c}\text { Mean } \\
\text { DBH } \mathbf{( c m )}\end{array}$ & $\begin{array}{c}\text { Mean tree } \\
\text { height } \mathbf{( m )}\end{array}$ & $\begin{array}{c}\text { Mean } \\
\text { Stand density } \\
\left(\text { tree } \cdot \mathbf{h m}^{-2}\right)\end{array}$ \\
\hline Young forest & 10 & 6.3 & 3.8 & 1600 \\
Middle-aged forest & 28 & 18.0 & 10.7 & 1255 \\
Near-mature forest & 31 & 20.3 & 12.3 & 1089 \\
Mature forest & 51 & 20.7 & 12.6 & 900 \\
Over-mature forest & 69 & 27.5 & 15.1 & 563 \\
\hline
\end{tabular}

2

3 
Table 2 (on next page)

Carbon distribution over the life cycle of Pinus tabuliformis plantation 
1 Table 2.Carbon distribution over the life cycle of Pinus tabuliformis plantation

\begin{tabular}{|c|c|c|c|c|c|c|c|c|c|}
\hline \multirow{3}{*}{$\begin{array}{c}\text { Forest } \\
\text { Age }\end{array}$} & \multicolumn{3}{|c|}{ Aboveground Carbon Content } & \multicolumn{6}{|c|}{ Underground Carbon Content } \\
\hline & \multirow{2}{*}{$\begin{array}{c}\text { Leaf } \\
\left(\mathbf{g} \cdot \mathbf{k g}^{-1}\right)\end{array}$} & \multirow{2}{*}{$\begin{array}{l}\text { Branch } \\
\left(\mathrm{g} \cdot \mathbf{k g}^{-1}\right)\end{array}$} & \multirow{2}{*}{$\begin{array}{c}\text { Trunk } \\
\left(\mathbf{g} \cdot \mathbf{k g}^{-1}\right)\end{array}$} & \multicolumn{2}{|c|}{ Fine Roots（0.5m） } & \multirow{2}{*}{$\frac{\left(\mathrm{g} \cdot \mathrm{kg}^{-1}\right)}{40-60 \mathrm{~cm}}$} & \multicolumn{3}{|c|}{ Fine Roots（1m）（g· $\left.\mathrm{kg}^{-1}\right)$} \\
\hline & & & & $0-20 \mathrm{~cm}$ & $20-40 \mathrm{~cm}$ & & $0-20 \mathrm{~cm}$ & $20-40 \mathrm{~cm}$ & $40-60 \mathrm{~cm}$ \\
\hline YF & $\begin{array}{c}489.83 \pm 1 \\
05 \mathrm{AB}\end{array}$ & $\begin{array}{c}471.43 \pm 2 \\
07 \mathrm{BC}\end{array}$ & $\begin{array}{c}503.72 \pm 6 \\
43 \mathrm{~A}\end{array}$ & $\begin{array}{c}463.83 \pm 2 \\
38 \mathrm{CD}\end{array}$ & $\begin{array}{c}461.88 \pm 4 \\
07 \mathrm{CD}\end{array}$ & $\begin{array}{c}415.20 \pm 5 \\
66 \mathrm{DE}\end{array}$ & $\begin{array}{c}458.20 \pm 14 \\
.87 \mathrm{CD}\end{array}$ & $\begin{array}{l}448.85 \pm 31 \\
\quad 74 \mathrm{CDE}\end{array}$ & $\begin{array}{c}422.32 \pm 18 \\
.50 \mathrm{E}\end{array}$ \\
\hline MAF & $\begin{array}{c}505.90 \pm 2 . \\
72 \mathrm{~A}\end{array}$ & $\begin{array}{c}335.00 \pm 1 \\
59 \mathrm{E}\end{array}$ & $\begin{array}{c}503.17 \pm 1 \\
0.17 \mathrm{~A}\end{array}$ & $\begin{array}{c}479.63 \pm 6 \\
18 \mathrm{~B}\end{array}$ & $\begin{array}{c}458.77 \pm 12 \\
.65 \mathrm{CD}\end{array}$ & $\begin{array}{c}453.37 \pm 9 \\
86 \mathrm{CD}\end{array}$ & $\begin{array}{c}471.27 \pm 12 \\
.33 \mathrm{BC}\end{array}$ & $\begin{array}{c}445.40 \pm 19 . \\
89 \mathrm{D}\end{array}$ & $\begin{array}{c}451.20 \pm 10 \\
.21 \mathrm{CD}\end{array}$ \\
\hline NMF & $\begin{array}{c}509.00 \pm 3 . \\
72 \mathrm{~A}\end{array}$ & $\begin{array}{c}335.47 \pm 2 . \\
57 \mathrm{~F}\end{array}$ & $\begin{array}{c}489.87 \pm 2 \\
38 \mathrm{AB}\end{array}$ & $\begin{array}{c}465.13 \pm 18 \\
.76 \mathrm{CD}\end{array}$ & $\begin{array}{c}456.77 \pm 2 \\
21 \mathrm{DE}\end{array}$ & $\begin{array}{c}453.80 \pm 12 \\
.90 \mathrm{DE}\end{array}$ & $\begin{array}{l}480.37 \pm 4 \\
\quad 71 \mathrm{BC}\end{array}$ & $\begin{array}{c}451.93 \pm 15 . \\
85 \mathrm{DE}\end{array}$ & $\begin{array}{c}436.73 \pm 19 \\
.09 \mathrm{E}\end{array}$ \\
\hline MF & $\begin{array}{c}497.83 \pm 3 \\
62 \mathrm{~B}\end{array}$ & $\begin{array}{c}339.67 \pm 1 \\
93 \mathrm{D}\end{array}$ & $\begin{array}{c}509.73 \pm 1 \\
0.03 \mathrm{~A}\end{array}$ & $\begin{array}{c}463.10 \pm 0 . \\
76 \mathrm{C}\end{array}$ & $\begin{array}{c}464.43 \pm 2 . \\
00 \mathrm{C}\end{array}$ & $\begin{array}{c}462.33 \pm 3 \\
81 \mathrm{C}\end{array}$ & $\begin{array}{c}471.60 \pm 2 . \\
42 \mathrm{C}\end{array}$ & $\begin{array}{c}468.67 \pm 4.4 \\
5 \mathrm{C}\end{array}$ & $\begin{array}{c}465.97 \pm 0 . \\
29 \mathrm{C}\end{array}$ \\
\hline OMF & $\begin{array}{c}494.80 \pm 1 \\
11 \mathrm{~A}\end{array}$ & $\begin{array}{c}335.17 \pm 1 \\
72 \mathrm{~F}\end{array}$ & $\begin{array}{c}504.90 \pm 6 \\
17 \mathrm{~A}\end{array}$ & $\begin{array}{c}471.43 \pm 6 \\
26 \mathrm{~B}\end{array}$ & $\begin{array}{c}449.07 \pm 6 \\
44 \mathrm{DE}\end{array}$ & $\begin{array}{c}439.67 \pm 15 \\
.88 \mathrm{E}\end{array}$ & $\begin{array}{c}462.57 \pm 3 . \\
44 \mathrm{BC}\end{array}$ & $\begin{array}{c}456.93 \pm 7.8 \\
0 \mathrm{CD}\end{array}$ & $\begin{array}{c}455.80 \pm 4 . \\
7 C D\end{array}$ \\
\hline
\end{tabular}

2 Notes: Different uppercase letters indicate significant differences between the carbon content of different

3 organs in the same forest age $(p<0.05)$. YF: Young forest, MAF: Middle-aged forest, NMF: Near-mature

4 forest, MF: Mature forest, OMF: Over-mature forest. 
Figure 1

Carbon content of leaf (A), branch (B) and trunk (C).

Different lowercase letters indicate significant differences among different forest ages ( $p<$ 0.05). YF: Young forest, MAF: Middle-aged forest, NMF: Near-mature forest, MF: Mature forest, OMF: Over-mature forest.

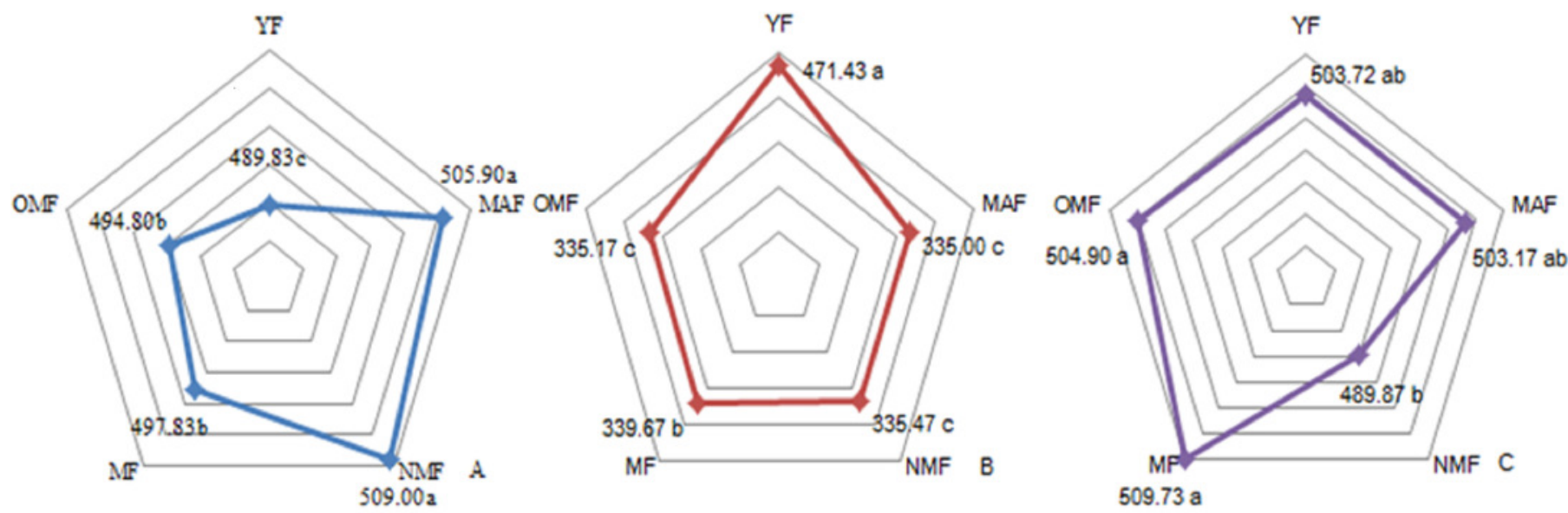




\section{Figure 2}

Carbon content of fine roots $(0.5 \mathrm{~m})(\mathrm{A})$ and fine roots $(1 \mathrm{~m})(B)$

Different uppercase letters in the same forest age indicate significant differences between different soil layers, while different lowercase letters in the same soil layer indicate significant differences between different forest ages $(p<0.05)$. YF: Young forest, MAF: Middle-aged forest, NMF: Near-mature forest, MF: Mature forest, OMF: Over-mature forest.
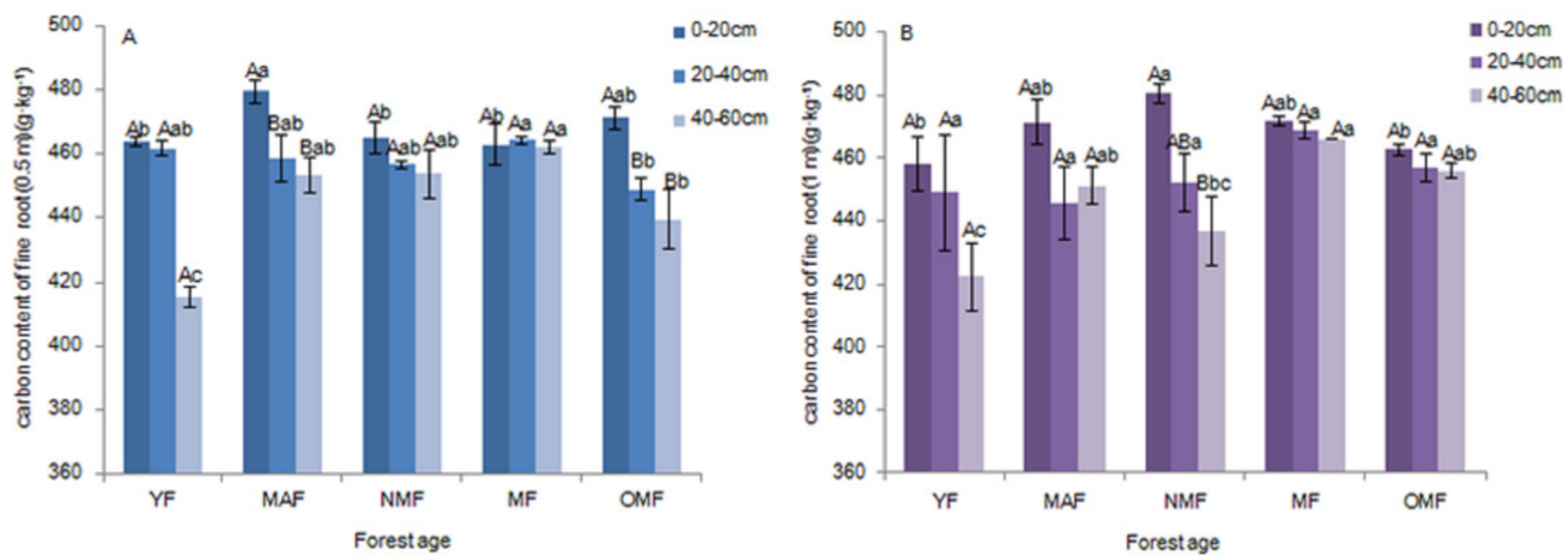
Figure 3

Soil TC content (A), soil TN content (B), soil TP content (C) and soil AP content (D).

Different uppercase letters in the same forest age indicate significant differences between different soil layers, while different lowercase letters in the same soil layer indicate significant differences between different forest ages $(p<0.05)$. YF: Young forest, MAF:

Middle-aged forest, NMF: Near-mature forest, MF: Mature forest, OMF: Over-mature forest.
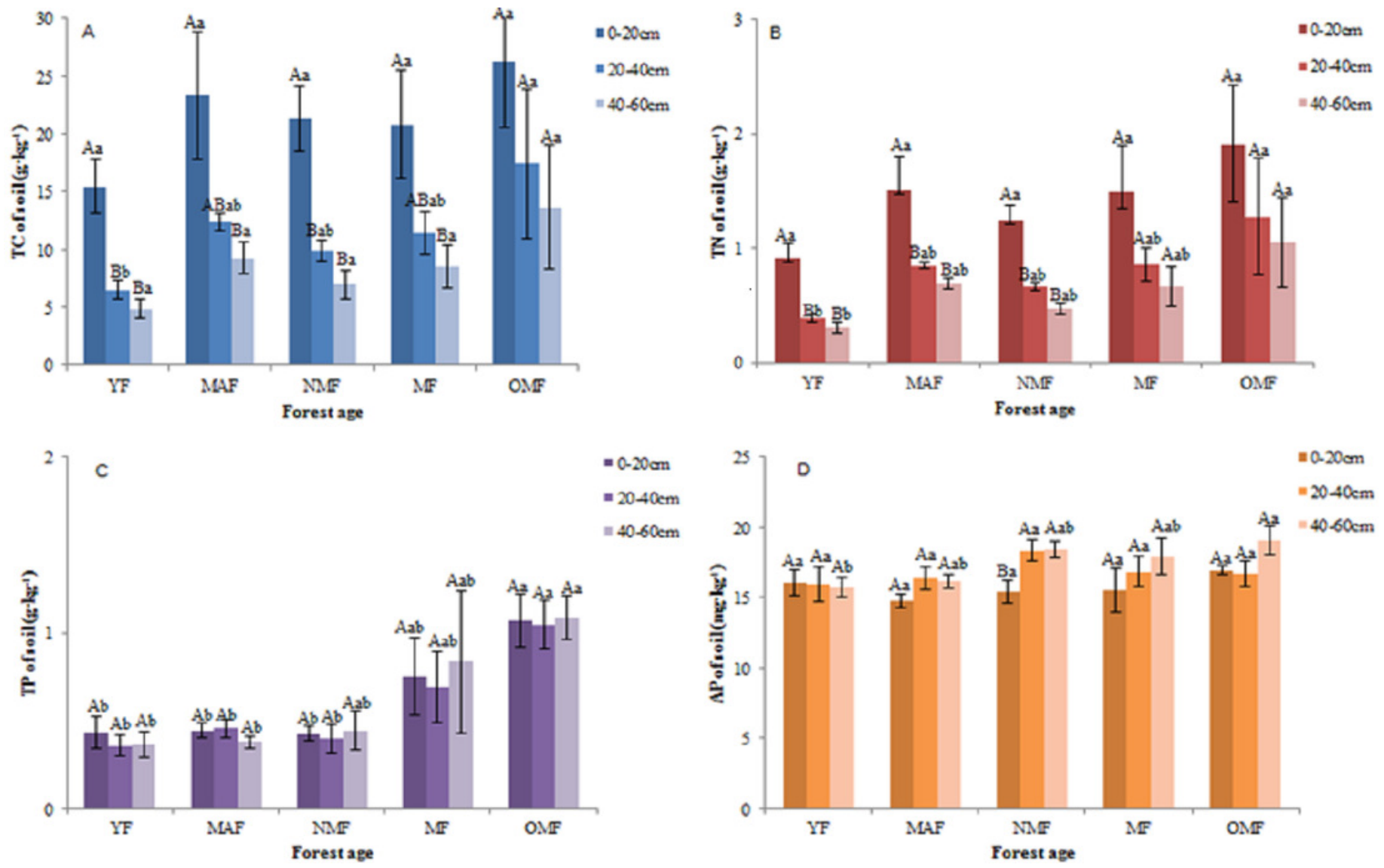
Figure 4

Soil TC: TN (A), Soil TC: TP (B) and Soil TN: TP (C).

Different uppercase letters in the same forest age indicate significant differences between different soil layers, while different lowercase letters in the same soil layer indicate significant differences between different forest ages $(p<0.05)$. YF: Young forest, MAF:

Middle-aged forest, NMF: Near-mature forest, MF: Mature forest, OMF: Over-mature forest.

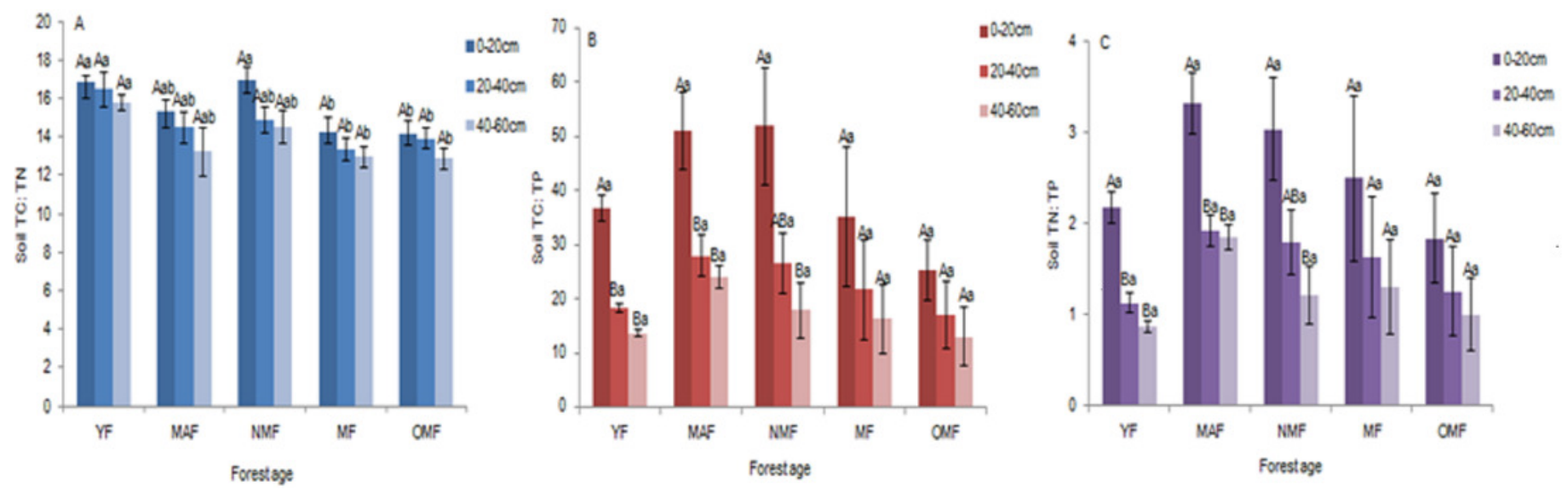


Figure 5

The linear relationship between the components of $\mathrm{YF}(\mathrm{A})$ and $\mathrm{MF}(\mathrm{B}, \mathrm{C})$.

The correlation $(p<0.05)$ is indicated by a red line. YF: Young forest, MF: Mature forest.
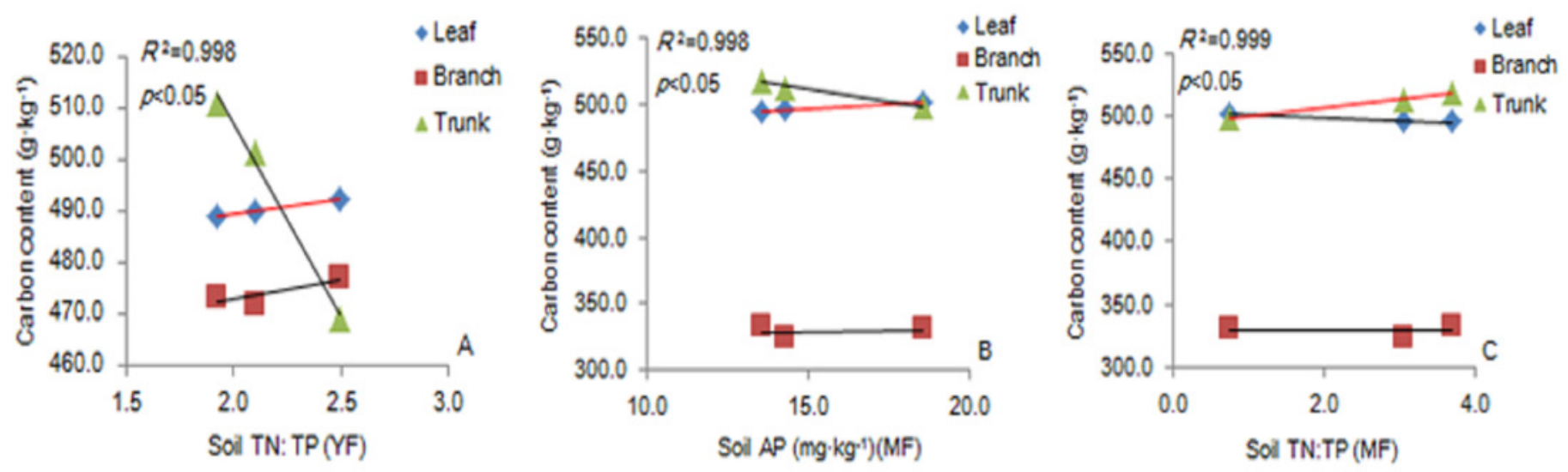
Figure 6

The linear relationship between the components of $\mathrm{YF}(A, B, C, D), \operatorname{MAF}(E), \operatorname{NMF}(F, G)$, MF (H) and OMF (I).

The correlation $(p<0.05)$ is indicated by a red line. YF: Young forest, MAF: Middle-aged forest, NMF: Near-mature forest, MF: Mature forest, OMF: Over-mature forest.
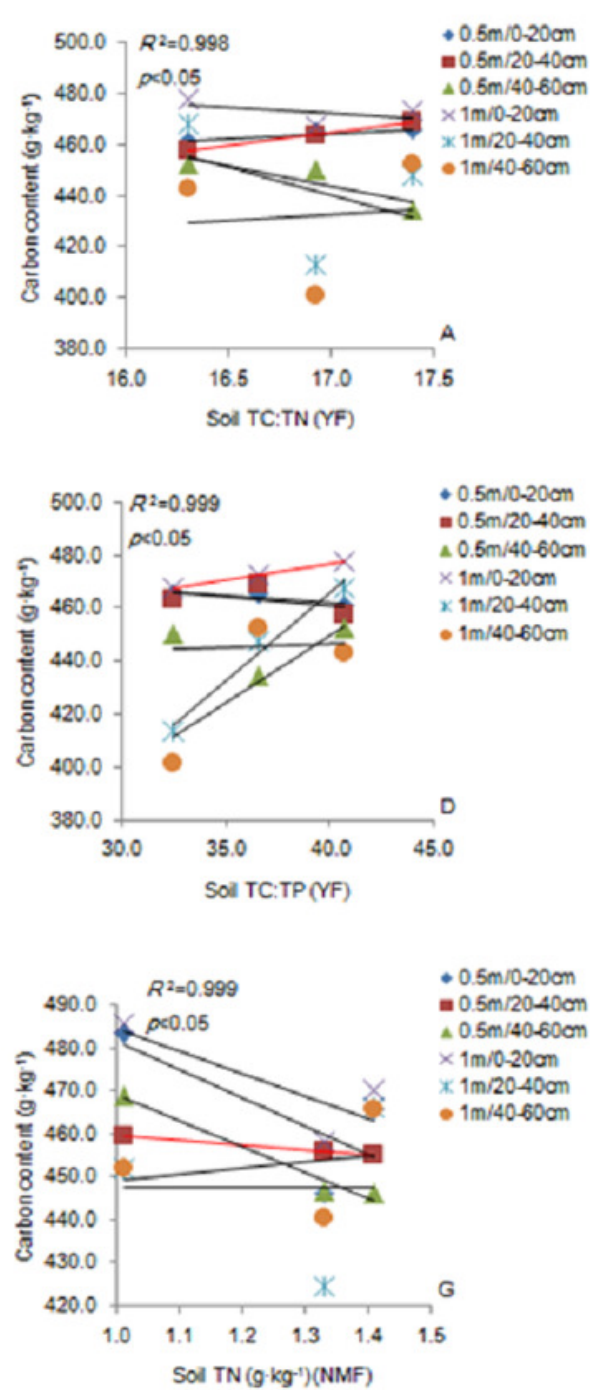
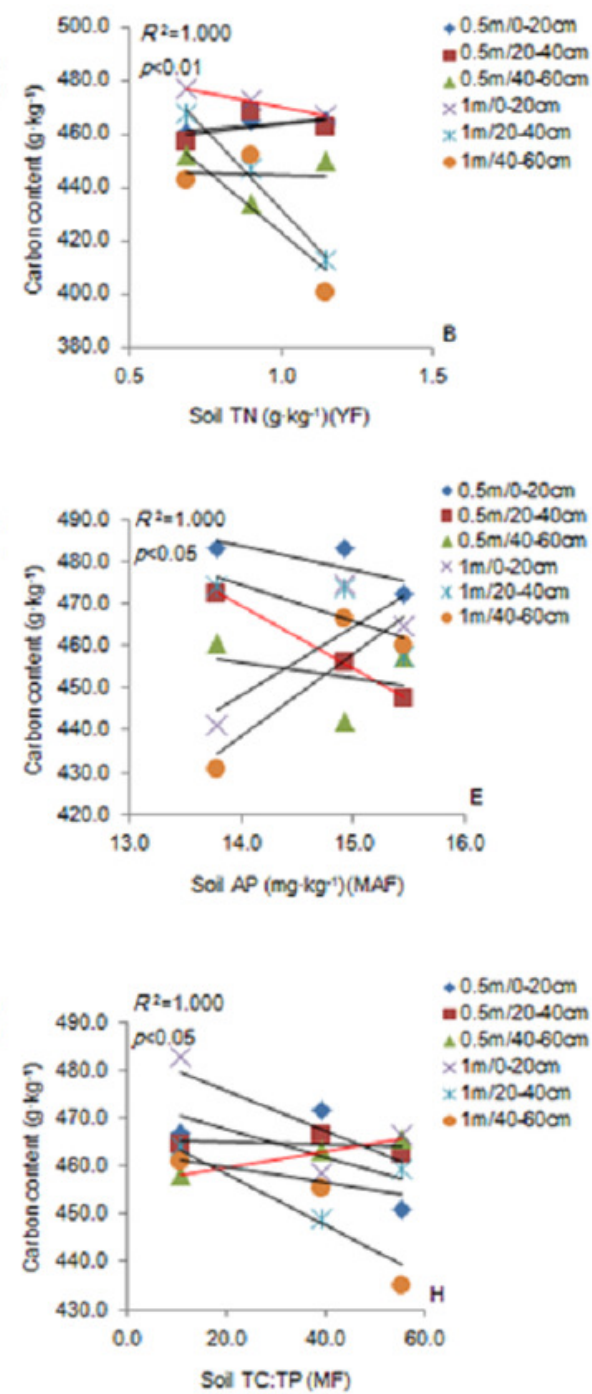
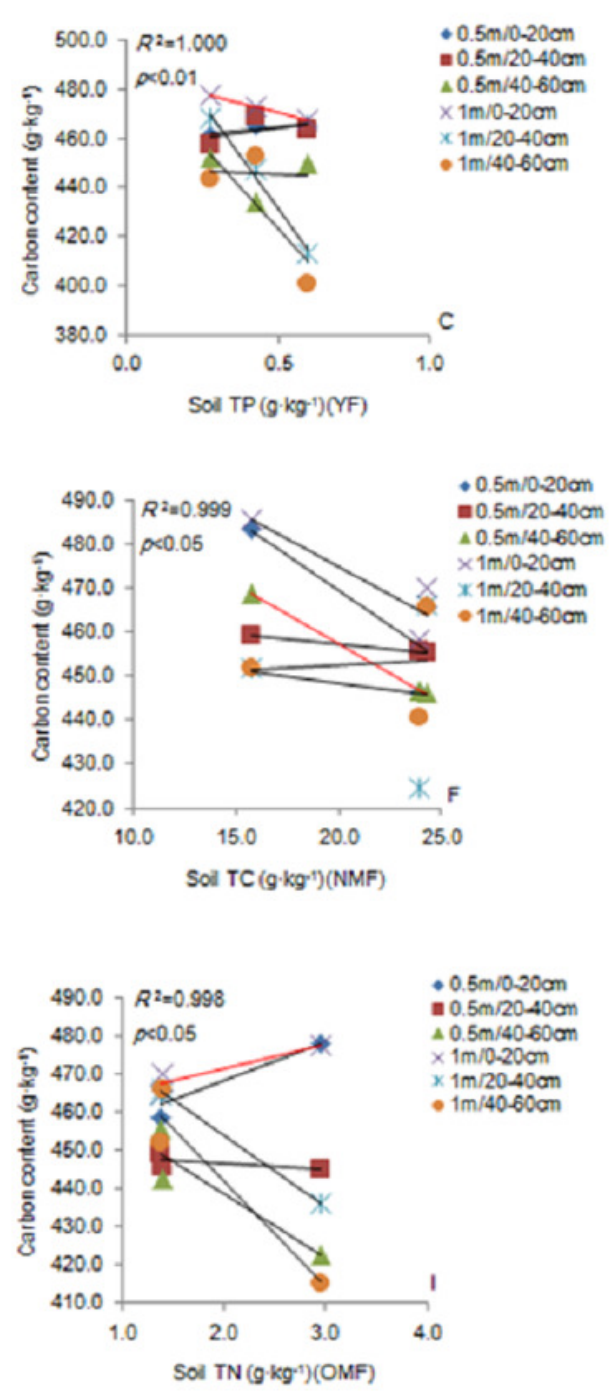